\title{
Standbunkt
}

On the future role of Councils for Sustainable Development

\section{How governments can do a better job}

\author{
Nachhaltige Entwicklung entsteht in einem Dialog zwischen \\ Wissenschaft, Politik und Zivilgesellschaft. Dabei gestalten \\ Nachhaltigkeitsräte diesen Kommunikationsprozess und bera- \\ ten die Regierung. Was sind die derzeitigen Herausforderungen \\ für diese Gremien und wie sollte deren zukünftige Entwicklung \\ aussehen? Von Frans W.R. Evers
}

$\mathbf{T}$ he EU Sustainable development strategy proposes that Member States undertake peer reviews of their national Sustainable development strategies (SDS). The Dutch government therefore invited experts to review their strategy. Among other recommendations in the summer of 2007, the peers advised on the non-existence of an advisory council on Sustainable development. The establishment of such councils is also a recommendation of the EU SDS. It is therefore amazing that the peers did not advise to create such a Sustainable development council (SDC) like the well functioning councils in other countries, for example Germany, Portugal and Belgium.

According to studies of the network of European Environment and Sustainable Development Advisory Councils (EEAC), SDCs cumulate and widen the functions of individual organisations of civil society. In Europe, around thirteen member states have national advisory councils that are explicitly engaged in the Sustainable development agenda. They have in common an emphasis on hearing both the voices from civil society as well as expertise from scientists.

In a 2007 empirical study of existing SDCs, Dr. Ingeborg Niestroy from EEAC explored two tasks and functions of SDCs, namely stimulating informed debate on Sustainable development and involving civil society. A core idea of an SDC is that its members have the chance and challenge to cover the span between their background or organisations and the demand in the council for open deliberation. Independent councils foster the dialogue of stakeholders among each other and they develop joint advice and recommendations. Councils try to transform a controversial political style of debate into a mutual comprehensive learning without circumventing the contrariness of issues. Council members are expected to carry results of the joint deliberations into their own organisation.

But it goes also far beyond this: SDCs are webbing into society by organising discussions in all kinds of formats with a wide range of actors. Sustainable development is a dynamic process of permanent negotiations, and most countries meanwhile characterise it as a learning process.

\section{Achieving unexpected agreements}

The Northwestern political culture of governments being amenable to dialogue and involvement of civil society, in rather corporatist settings with a stakeholder focus, has spread across Europe at least as an accepted approach. In some countries there is still a deficient information flow and consultation mechanisms. These situations typically correlate with a relatively low degree of self-organisation of civil society.

According to a 2005 EEAC study SD councils are a specific mechanism for fostering dialogue among different stakeholders, which has the potential for innovative approaches and solutions, and for achieving unexpected agreements. With their rather unique position of being established by governments, but being independent in their deliberations, they provide a potential for bridging the often perceived gap between government and non-governmental actors, and for transporting collective views and knowledge of civil society to the government. Most councils are valued by both government and stakeholders, and have a record of accomplishments.

Most recent the French government installed a SDC and other governments are near such a decision. I expect that in the coming years it will be necessary to change the focus of the climate problem from an environmental concern into a sustainable development issue.

This will in several cases lead to transformation of advisory bodies on environment into SDCs, or to a merger of different advisory bodies into one such council. We will see resistance from social-economic councils against such a development, since many people, including scientists, do not accept Sustainable development as a better option for societal progress than the traditional economic growth philosophy.

We will also see a demand from government to civil society including the business community to create new solutions. The traditional government's way is no longer capable to produce effective solutions. Sustainable development councils in several countries are facing a formidable challenge: confront knowledge and science with the views and interests of all stakeholders and present idea's that allow governments to do their job better.

Frans Evers ist Vorsitzender des Lenkungsausschusses des Verbunds der Europäischen Umweltund Nachhaltigkeitsräte (EEAC) and außenordent-

licher Professor an der Tias Business School der Tilburg Universität in den Niederlanden. Frans Evers, EEAC, c/o MiNa-Raad, Kliniekstraat 25, 1070 Brüssel, Niederlande. E-Mail: f.evers@hilverbeek.nl, Internet: http://www.eeac-net.org 
(c) 20I0 Authors; licensee IÖW and oekom verlag. This is an article distributed under the terms of the Creative Commons Attribution Non-Commercial No Derivates License (http://creativecommons.org/licenses/by-nc-nd/3.o/), which permits unrestricted use, distribution, and reproduction in any medium, provided the original work is properly cited. 